\title{
Influence of Clay Mineralogy on Plasticity of Lateritic Soils
}

\author{
M. Alhassan ${ }^{1,2}$, A. M. Mustapha ${ }^{3}$ and E. Mesaiyete ${ }^{4}$ \\ ${ }^{I}$ Department of Geotechnics and Environmental Engineering, Belarusian National Technical University, Minsk, \\ Belarus \\ ${ }^{2,3}$ Department of Civil Engineering, Federal University of Technology, Minna, Nigeria \\ ${ }^{4}$ APM Terminals Apapa Ltd, Apapa, Lagos, Nigeria
}

\begin{abstract}
Lateritic soils samples taken from four different locations were subjected to plasticity tests and clay mineralogical analysis using method of X-ray diffraction. The results of the plasticity test of the soils indicate liquid limit values of the soils ranging between 35.00 to $52.30 \%$. The plasticity index and linear shrinkage of the soils ranges from 15.73 to $24.70 \%$ and 8.21 to $16.64 \%$ respectively. The clay mineralogy results show three of the soil samples, having lower plasticity values, consisting of mostly kaolinite as clay mineral, while the soil having relatively higher plasticity value (liquid limit of $52.30 \%$, plasticity index of $24.70 \%$ and linear shrinkage of $16.64 \%$ ), shows presence of a mineral of the chlorite group as the dominant clay mineral. This shows that the relatively lower and higher water affinity of kaolinite and chlorite respectively, present in this soils were responsible for the recorded plasticity values.
\end{abstract}

Keywords: Clay mineral, Lateritic soil, Plasticity, X-ray diffraction.

\section{Introduction}

Laterite is a common construction material available in almost all the countries of the humid tropics of the world. It is a soil group commonly found in the leached soils of the humid tropics and is formed under weathering systems that cause the process of laterization [1]. Its formation is favoured by the factors encouraging laterization processes such as high intensity rainfall, high vegetation cover, permeable soil profile, alternating ground water movement, etc. Laterite soils can be used as base course for roads, in some cases, without any improvement. But there are other cases where laterization process is not complete and soil groups such as Laterite, lateritic and laterized soils are formed. These soils may contain substantial amount of silica in the form of clay silicate minerals [2].

Just as the concept of particle size and grading is readily appreciated when dealing with coarse-grained soils, in the case of soils, consisting predominantly of clays (clay soils), plasticity takes centre stage. Clay soils are somehow fundamentally different from coarse-grained soils, since they exhibit the property of plasticity whereas sands and gravels do not.

Plasticity is the ability of a material to be moulded without fracturing. In soils, it is due to the electrochemical behaviour of the clay minerals and as such, is unique to soils containing clay mineral particles. These are plate-like structures which typically possess a negative electrical charge on their surface, brought about by inherent flaws within the chemical lattice. In nature, this negative charge is cancelled out by cations $\left(\mathrm{Na}^{+}, \mathrm{Ca}^{++}\right.$etc.) present in the pore water. The positive to negative attraction, between the cation and the clay mineral, provides a network of bonds throughout the clay mass. Also, because water molecules themselves are polarised, water molecules immediately adjacent to the minerals becomes attracted and bonded (adsorbed) to the surface to form an 'adsorption complex'. Since these electrochemical bonds act through the water surrounding the clay particles, the attraction is maintained even when large deformations take place between clay particles, to produce the phenomenon of plasticity [3]. This unique behavior of clay soils depends on the surface area of the clay particles. This to a large extend determines and or affects the physico-mechanical properties of the soils [4-8]. The surface area of clay particle depends on the type of the clay mineral.

Geotechnical characteristics and field performances of lateritic soils can therefore, be interpreted in the light of genesis and pedogenic factors, degree of weathering, clay-size content and clay mineralogy. The clay minerals present exert considerable influence on geotechnical properties such as plasticity, shear strength, compressibility etc.

The crystalline mineralogical components of clay fraction of soils are most readily identified by the powder method of x-ray diffraction analysis [9-11]. This is generally combined with various auxiliary pretreatments of the sample. Differential thermal analysis is also commonly employed and for certain uses such as identifying non-crystalline constituents. For this study, the x-ray diffraction analysis was used. 


\section{Justification}

Clay mineral analysis of soils is unfortunately, not usually employed in the routine examination of soils for engineering projects. This is partly because the techniques and equipments are beyond the resources of the ordinary soil testing laboratory. Although, in the study of the lateritic soil to be used for engineering constructions, the consideration (study) of clay minerals, present in the soil, have proved to be very useful in understanding the soils' behaviours and therefore, help in determining their applications. Alhassan et al [12], using Minna lateritic soils as a case study, conducted a study on the clay mineralogy of lateritic soils derived from granite basement, but the influence of the mineralogy on the plasticity of these soils have not been studied.

\section{Location and Geology of the Study Area}

The lateritic soil samples used for this work were collected from four locations around the city of Minna, Niger State, Nigeria, at: $9^{\circ} 40^{\prime} 17.94^{\prime \prime} \mathrm{N}, 6^{\circ} 46^{\prime} 27.29^{\prime \prime} \mathrm{E}$; $9^{\circ} 30^{\prime} 59.27^{\prime \prime} \mathrm{N}, 6^{\circ} 35^{\prime} 42.32^{\prime \prime}$ E; $9^{\circ} 35^{\prime} 08.22^{\prime \prime}$ $\mathrm{N}, 6^{\circ} 30^{\prime} 10.07^{\prime \prime} \mathrm{E}$; and $9^{\circ} 40^{\prime} 52.32^{\prime \prime} \mathrm{N}, 6^{\circ} 26^{\prime} 44.76^{\prime \prime} \mathrm{E}$ for sample $1,2,3$ and 4 respectively. According to Wright [13], the residual soil in this area is under laid by a granite basement and is surrounded to the north and south by older basement rocks of the Precambrian to upper Cambrian age, and illo-group formation to the northwest. The area is drained by several rivers which are tributaries of River Niger. Soils in this area belong to ferruginous tropical soils derived from acid igneous and metamorphic rocks [2].

\section{Methodology}

Lateritic soil samples used for this study were collected using disturbed sampling method. The soil samples were air dried, and index properties test and clay minerals analysis of the soils were conducted on the samples. Index properties determined included Natural Moisture Content (NMC), Specific gravity $\left(\mathrm{G}_{\mathrm{s}}\right.$ ) consistency (Liquid Limit, LL and Plastic Limit, PL) and Linear Shrinkage (LS) tests. All these tests were conducted in accordance with BS 1377 [14]. The results are presented in tab. 1. The results of LL, PL and LS recorded in the table are average of at least ten trials, whose readings were within $\pm 2 \%$ of the averages.

For determining the clay minerals in the soils, x-ray diffraction analysis was used.

\section{$X$ - Ray Diffraction Analysis}

This test was carried out to determine the clay minerals present in the samples. Automated x-ray diffractometer was used. It is made up three main components or parts:

i) The diffractometer;

ii) The computer system and

iii) Coolers, for cooling the diffractometer.

The sample were pulverized and sieved through $75 \mu \mathrm{m}$ sieve size. In this test three stages were involved:

\section{Bulk analysis}

A small portion of each of the sieved sample was put in the sample compartment. The scanning angles chosen were between $0^{\circ}-70^{\circ}$. The material was scanned by the $\mathrm{X}$ - ray source impinging rays on the sample in the sample holder, while the goniometer (where the sample holder sits) spun and rotated through the set angles.

The receiver in the equipment detected the number of rays that bounced of the sample in the form of "counts". The counts are a measure of the intensity of the presence of the minerals i.e. the more a mineral is present, the higher the counts. A graph of counts on the ordinate and diffraction angles on the abscissa was plotted by the computer and comparisons were made with an already existing database present in the computer. The database is an index prepared by American Society for Testing and Materials (ASTM). The 40 minerals with the highest presence were identified by this comparison.

\section{Clay Fraction Analysis}

The clay fraction was extracted by using the centrifuge. The sizes less than $2 \mu \mathrm{m}$ fall under clay fraction. A film was made of the clay extracted and placed on a tiny slide of about $10 \mathrm{~mm}$ diameter. This slide was placed on the sample holder and the angle were set to rotate between $0^{\circ}-40^{\circ}$ because the clay peaks appear within this range of angles. The process from scanning to the plotting of the diffractograph was repeated. In this case, the graph plotted was not compared directly with the database but inferences from the usual behaviour of the main clay groups (kaolinites, smectites, micas and chlorites) were used to determine the clay groups present. For example, kaolinite and chlorites have very sharp peak around $12^{\circ}$ and $12.5^{\circ}(2 \theta)$.

\section{Confirmatory Tests}

This consists of two stages: 
i) The first stage of the confirmatory test was glycolation of the samples. This was done by exposure of the clay fractions to ethylene fumes. After this the samples were again scanned at angles between $0-15^{\circ}$. This was because common clay minerals appear around this range. The results obtained were then checked by inference, from usual behaviour of minerals.

ii) The samples were then heated in a furnace for up to $550^{\circ} \mathrm{C}$, then scanned again at angles between $0-15^{\circ}$. This test was to check for kaolinites. Kaolinites cannot sustain high heat, therefore their lattice structures disintegrate, becoming mullite (non-crystalline structures or minerals with destroyed structures). On scanning after heating, kaolinites' peaks disappeared.

\section{Results and Discussion}

\section{Index properties of the soils}

The results of the index properties of the soils, shown in table 1, indicate the LL values of the soils ranging between 35.00 to $52.30 \%$. The Plasticity Index $\left(\mathrm{I}_{\mathrm{p}}\right)$ and Linear Shrinkage (SL) of the tested soil samples ranges between 15.73 to $24.70 \%$ and 8.21 to $16.64 \%$ respectively. The higher values for these properties were recorded from sample 2 . The plasticity of samples 1,3 and 4 indicates that their clay fractions are of low plasticity according to Unified Soil Classification System (USCS) [15]. Sample 2 contained clay of high plasticity. These results agree with earlier findings by Alhassan [16] and Mustapha and Alhassan [17].

Table 1: Index properties of the soil samples

\begin{tabular}{|c|c|c|c|c|c|c|}
\hline \multirow{2}{*}{ Sample } & \multicolumn{5}{|c|}{ Property } \\
\cline { 2 - 8 } & $\begin{array}{c}\text { Natural Moisture } \\
\text { Content (\%) }\end{array}$ & $\begin{array}{c}\text { Specific } \\
\text { Gravity }\left(\mathrm{G}_{\mathrm{s}}\right)\end{array}$ & $\begin{array}{c}\text { Liquid Limit } \\
(\%)\end{array}$ & $\begin{array}{c}\text { Plastic } \\
\text { Limit }(\%)\end{array}$ & $\begin{array}{c}\text { Plasticity } \\
\text { Index }(\%)\end{array}$ & $\begin{array}{c}\text { Linear } \\
\text { Shrinkage }(\%)\end{array}$ \\
\hline 1 & 10.95 & 2.70 & 35.00 & 19.27 & 15.73 & 8.21 \\
\hline 2 & 29.84 & 2.65 & 52.30 & 27.60 & 24.70 & 16.64 \\
\hline 3 & 19.06 & 2.70 & 37.20 & 14.84 & 22.36 & 9.04 \\
\hline 4 & 22.48 & 2.70 & 42.50 & 21.70 & 20.80 & 14.29 \\
\hline
\end{tabular}

\section{Clay Mineralogical Composition of the Samples}

The bulk analysis of sample 1 did not show any of its most prominent minerals as clay, but a very high presence of quartz $\left(\mathrm{SiO}_{2}\right)$ and a moderate intensity of Lanthanum silicate $\left(\mathrm{La}_{2} \mathrm{SiO}_{5}\right)$ and Olivine $\left(\mathrm{MgFeSiO}_{2}\right)$. The clay fraction analysis showed a sharp peak between angle $12^{\circ}$ and $13^{\circ}$ suggesting the presence of a kaolinite or chlorite. Analysis of the sample after glycolation showed negligible increments in basal spacing, and a sharp peak at angle $12^{\circ}(2 \theta)$, confirmed this. After heat treatment, disappearance of peak occurred, confirming the presence of kaolinite. The peak count of the sample was 14.83. The presence of kaolinite as the clay mineral in this sample is responsible for the relatively low plasticity of the soil. Kaolinite, generally have relatively low affinity for water $[18-20]$.

Sample 2 also showed a very high presence of quartz in the sample's bulk analysis. But this also showed presence of two clay minerals, a mica called lepidolite $\left(\mathrm{K}(\mathrm{LiAl})_{3}\left(\mathrm{Si}_{2} \mathrm{Al}_{4}\right)_{4} \mathrm{O}_{10}\right)$ and a kaolinite called halloysite $\left(\mathrm{Al}_{2} \mathrm{Si}_{2} \mathrm{O}_{5}(\mathrm{OH})_{4} \cdot 2 \mathrm{H}_{2} \mathrm{O}\right)$. The analysis of the clay fraction confirmed this with a sharp peak appearing at angle $12.5^{\circ}(2 \theta)$. After glycolation, a slight increment in basal spacing was observed due to the swelling minerals (halloysite and lepidolite). A slightly diffused peak appeared between angles $12^{\circ}$ and $13^{\circ}(2 \theta)$. After heat treatment the peak remained. Since kaolinite's peaks disappear upon heat treatment, this occurrence suggested the presence of a chlorite. The glycolation analysis counts was 34.2 which is lower than the heat treatment analysis counts of 39.0 suggesting that lepidolite (a chlorite group) is more prominent. This further confirms with the relatively high liquid limit value obtained for this sample, since this type of clay mineral have relatively higher water affinity $[20,21]$.

The bulk analysis of sample 3, like sample 1, did not show a clay mineral as one of its most prominent minerals. Quartz (silicon oxide $\left(\mathrm{SiO}_{2}\right)$ had the highest presence. Also Boron nitrite (BN) was very prominent. The analysis of the clay fraction carried out showed a peak appearing between angles $12^{\circ}$ and $13^{\circ}(2 \theta)$ hinting that a kaolinite or chlorite is present in the sample. After heat treatment, the analysis showed an absence of a peak, i.e. no peak appeared, confirming a kaolinite's presence. The peak count of the sample was 66. The presence of kaolinite as the clay mineral in this sample was responsible for the relatively low plasticity of the soil.

Sample 4 showed a very high presence of quartz in its bulk analysis. However, the presence of kaolinite $\left(\mathrm{Al}_{2} \mathrm{Si}_{2} \mathrm{O}_{2}(\mathrm{OH})_{4}\right)$ as one of its most prominent minerals was detected, unlike other samples which reflected their clay presence only after heat treatment. Clay fraction analysis showed a sharp peak at angle $12^{\circ}(2 \theta)$, suggesting the presence of a kaolinite or chlorite. Analysis after glycolation showed negligible increments in basal spacing, and sharp peak at angle $12^{\circ}(2 \theta)$. Disappearance of the peak after heat treatment confirmed the presence of 
kaolinite in the soil sample. The peak count of the sample was 54.33. The presence of kaolinite as the clay mineral in this sample was responsible for the relatively low plasticity of the soil.

\section{Conclusion}

1. The plasticity results indicate that soil sample 1,3 and 4 are of low plasticity, while sample 2 is soil of high plasticity.

2. The X-ray diffraction analysis showed that soil samples 1,3 and 4 contain kaolinite as their main clay mineral, while soil sample 2 contain a mineral of the chlorite group (lipidolite) as its main clay mineral.

3. Since kaolinite has low affinity to water, this mineral was responsible for the low plasticity values recorded for samples 1,3 and 4 .

4. The relatively higher plasticity value recorded for soil sample 2 is as a result of the presence of chlorite clay mineral. Chlorite has relatively higher affinity for water.

\section{References}

[1] M. D. Gidigasu, Laterite Soil Engineering: Pedogenesis and Engineering Principles, Elsevier, Amsterdam, Netherlands, 1976.

[2] A. M. Mustapha, R. Jibrin, N. M. Etsuworo, and M. Alhassan, Stabilization of A-6 Lateritic Soil using Cold Reclaimed Asphalt Pavement. International Journal of Engineering and Technology (IJET), 2014, vol. 4 No. 1, $52-57$.

[3] Carter, M. and Bentley, S. Correlation of Soil Properties, Pentech Press Publishers, London, 1991, 3-4.

[4] S. Tembe, D. A. Lockner and T. F. Wong, Effect of Clay Content and Mineralogy on Frictional Sliding Behavior of Simulated Gouges: Binary and Ternary Mixtures of Quartz, Illite, and Montmorillonite, Journal of Geophysical Research, 2010, 115 , B03416.

[5] A. T. Sudjianto, K. B. Suryolelono, A. Rifa'I and I. B. Mochtarb, The Effect of Variation of Plasticity Index and Activity in Swelling of Expansive Soil, International Journal of Engineering \& Technology, 2011, 11(6), 142-148.

[6] H. C. Hardiyatmo, B. Suhendro and D. Djarwadi, Engineering Properties of Kaolinitic Clay as Core of Batutegi Dam: In New Developments in Dam Engineering, Proceedings of the $4^{\text {th }}$ International Conference on Dam Engineering, Edited by M. Wieland, Q. Ren, and J. S. Y. Tan, Taylor \& Francis, 2004, 289-296.

[7] R. G. Robinson and M. M. Allan, Effect of Clay Mineralogy on Coefficient of Consolidation, Journal of clay and clay minerals, 1998, 46(5), 596-600.

[8] S. Azam, Influence of Mineralogy on Swelling and Consolidation of Soils in Eastern Saudi Arabia, Canadian Geotechnical Journal, 2003, 40, 964-975.

[9] V. S. Shrivastava, X-ray Diffraction and Mineralogical Study of Soil: A Review, Journal of Applied Chemical Research, 2009 , vol. 9, 41-51.

[10] W. Harris and N. White, X-ray Diffraction Techniques for Soil Minerals Identification: In Method of Soil Analysis, part 5, Mineralogical Methods; SSSA Book Series, 2007, No. 5, 1-2.

[11] Y. Deng, G. N. White, and J. B. Dixon, Soil Mineralogy Manual, $11^{\text {th }}$ edition, Dept. of Soil and Crop Science, Texas A \& M University, College Station, Texas, 2009, 1-3.

[12] M. Alhassan, E. Mesaiyete and A.M. Mustapha. Clay Mineralogy of Lateritic Soils Derived from Granite Basement-A Case Study of Minna Lateritic Soils. Electronic Journal of Geotechnical Engineering (EJGE), Oklahoma, USA, 2012, vol. 17(M), 1897-1903.

[13] Wright, J. B. Volcanic rocks in Nigeria", In Geology of Nigeria edited by Kogbe, C. A., 1989, 125-175.

[14] B. S.1377, Methods of Testing Soil for Civil Engineering Purposes, British Standards Institute, London, England, 1990.

[15] ASTM, Standard Test Method for Classification of Soils for Engineering Purposes. American Association for Testing and Materials, ASTM Designation D2487-1969, 1970.

[16] M. Alhassan, Classification of Minna Laterite, Proceedings of the Papers Presented at the $7^{\text {th }}$ Annual Engineering Conference, Federal University of Technology, Minna, Niger State. 2006, 40-44.

[17] A. M. Mustapha and M. Alhassan, Chemical, Physico-chemical and Geotechnical Properties of Lateritic Weathering Profile Derived from Granite Basement. Electronic Journal of Geotechnical Engineering (EJGE), Oklahoma, USA, 2012, vol. 17(J), 18851894.

[18] R. G. Loucks, M. M. Douge, and W. E. Galloway, Importance of Secondary Leaching Porosity in Lower Tertiary Sandstone Reservoir along the Gulf Coast, Bur. Econ. Geology, Geol. Circ., Univ. Texas: Texas, 1980, 80-102.

[19] R. G. Loucks, M. M. Douge, and W. E. Galloway, Am. Assoc. Petroleum Geologists, Mem, 1984, $15-37$.

[20] Ahmad, W. Contrast in Clay Mineralogy and their Effect on Reservoir Properties in Sandstone Formations, Bulletin of Chemical Society, Ethiopia. 2008, 22(1), 41-65.

[21] A. Namdar, Mineralogy in Geotechnical Engineering, Journal of Engineering Science and Technology Review. Kalava. 2010, 3 (1), 108-110. 